Finally, we can affirm that our conclusions were correct and reflect a large cohort and a large daily practice, which can be interpreted in view of this scientific work.

Romero Henrique Carvalo Bertrand

João Batista Santos Garcia, TSA

Caio Márcio Barros de Oliveira, TSA

Adriana Leite Xavier Bertrand

\section{Barotrauma Pulmonar no Intra-Operatório de Procedimento Cirúrgico Oftalmológico. Relato de Caso}

(Rev Bras Anestesiol, 2008;58:63-68)

\section{Sra. Editora,}

Direito de Resposta (Lei no 2/99 de 13 de janeiro de 1999) referente ao "Relato de Caso: Barotrauma Pulmonar no Intra-Operatório de Procedimento Cirúrgico Oftalmológico." Esclarecimento público: o caso apresentado na Revista Brasileira de Anestesiologia ocorreu no Hospital Municipal Souza Aguiar - Rio de Janeiro, RJ, em 21/02/2005 e foi reportado ao Controle de Qualidade e Assistência Técnica da HB Hospitalar Indústria e Comércio Ltda. (fabricante do aparelho) em 25/02/2005, que iniciou a análise de causa conforme procedimentos internos e requisitos pertinentes a:

- Registro ANVISA no 10261120011.

- Certificado IEC MC, ELM-3678 de 28/11/2001 (Segurança Elétrica e Compatibilidade).

- Certificado ISO 9.000 no CE,SIQ-803.

- Certificado Boas Práticas de Fabricação (ANVISA) oo 179127/07-3.

Com os resultados dos testes e ensaios executados pela Análise de Riscos, ficou caracterizado que o aparelho de anestesia modelo Conquest 3000 , série 2369 , e seus acessórios NÃO apresentaram nenhuma não-conformidade nos processos avaliados:

- Projeto;

- Segurança;

- Desempenho;

- Montagem;

- Ergonomia;

- Atendimento aos requisitos estatutários; e

- Controle de Qualidade.

Os resultados positivos foram apresentados ao responsável pela identificação do ocorrido do Hospital supracitado, Dra. Lília Portela, Chefe do Serviço de Anestesiologia em 17 de março de 2005 por meio dos documentos comprobatórios (laudos técnicos) e formulários de trâmite, conforme o caso.

De acordo com a análise de causa, a situação ocorreu devido a:

1. O aparelho em questão foi fornecido, a pedido do cliente, com um tubo liso e em silicone, com cerca de $1,20 \mathrm{~cm}$ de comprimento, com intermediários acopláveis somente no ramo inspiratório do ventilador, e para possibilitar a montagem de sistema totalmente aberto, utilizando para isso, além do tubo, uma válvula unidirecional.

2. Conforme demonstrado nas fotos da reportagem, o tubo é demasiadamente longo, não sendo o original de fábrica destinado a essa aplicação (interligar o ventilador ao filtro circular).

3. Na ocasião o cliente não soube explicar por que os tubos haviam sido trocados.

Ações Preventivas:

Por tratar-se de um provável erro involuntário do usuário, o departamento de engenharia da HB Hospitalar foi acionado imediatamente para que fosse tomada uma ação preventiva visando a evitar ocorridos semelhantes no futuro. Ficando estabelecido:

1. Utilizar tubos tipo traquéia que fossem lisos por dentro e com anéis reforçados por fora, o que impediria o acotovelamento do tubo e a interrupção de fluxo independentemente do grau de curvatura do mesmo (item de série na fabricação).

2. Orientação específica referente aos procedimentos na operação do filtro circular (montagem e simulações), inclusive com revisão do Manual do Aparelho com o item evidenciado.

3. Substituição imediata dos tubos nos aparelhos do cliente (que ficou satisfeito com a ação tomada e nos remeteu uma comunicação relatando as melhorias).

Conclusão:

Salientamos o fato de que a HB Hospitalar Indústria e Comércio Ltda. está no mercado há 55 anos na área de fabricação e comercialização de aparelhos de anestesia. É uma empresa certificada em todos os âmbitos nacionais e internacionais, conforme legislação pertinente e que comercializou cerca de 220 unidades de aparelhos de anestesia modelo Conquest 3000 , sem nunca haver identificado nenhuma não-conformidade ocasionada por falha em projeto, desempenho ou segurança. Todas essas afirmações podem ser verificadas nos órgãos de proteção ao consumidor, no site da ANVISA (www.anvisa.gov.br) ou com seus clientes em todo o Brasil e no exterior.

A publicação em questão deveria analisar todos os fatos, sobretudo as conclusões do fabricante e do cliente, mediante a gravidade do ocorrido, tornando público, além do estudo de caso, as ações corretivas executadas que demonstram a atuação voltada ao maior interessado que é o paciente/ cliente.

Muito obrigado,

Harry Baukelmann

Diretor

HB Hospitalar Ind. e Com Ltda. 


\section{Intraoperative Pulmonary Barotrauma During Ophthalmologic Surgery. Case Report}

(Rev Bras Anestesiol, 2008;58:63-68)

Mrs. Editor,

The Right to Rebut (Law Number 2/99 of January 13, 1999) regarding the case report: Intraoperative Pulmonary Barotrauma During Ophthalmologic Surgery.

Public Information: the case reported by the Revista Brasileira de Anestesiologia happened at the Hospital Municipal Souza Aguiar - Rio de Janeiro, RJ, Brazil, on 02/21/2005 and was reported to the Quality Control and Technical Support of HB Hospitalar Ind. e Com. Ltda. (manufacturer of the equipment) on $02 / 25 / 2005$, who initiated an analysis of the causes according to internal procedures and requirements regarding:

- ANVISA Registration Number 10261120011

- IEC, MC, and ELM-3678 Certification of 11/28/2001 (Electrical Safety and Compatibility)

- ISO 9000 Certificate Number CE,SIQ-803

- Good Practice of Manufacture Certificate (ANVISA) Number 179127/07-3

In which the results of Tests and Assays performed through Risk Analysis determined that the Anesthesia Machine Conquest 3000 , Series 2369, and its accessories DID NOT present any non-conformities in the processes evaluated:

- Project;

- Safety;

- Performance;

- Assembly;

- Ergonomics;

- Fulfillment of statutory requirements; and

- Quality Control

The positive results were presented to the person in charge of investigating the case at the above mentioned Hospital, Dr. Lília Portela, Chief of Anesthesiology, on March 17, 2005 through corroborating documents (Technical Reports) and procedure forms, according to each case.

According to the cause analysis, the situation occurred due to:

1. The equipment mentioned was furnished, as requested by the client, with a smooth silicone tube, approximately $1.20-\mathrm{cm}$ long and connectible intermediates only in the inspiratory branch of the ventilator to allow the assembly of a completely opened system using for this purpose a one-way valve, besides the tube.;

2. As can be seen in the report, the tube is excessively long, and it is not the original tube provided for this application (to connect the ventilator to the circular filter);

3. At the time, the client could not explain why the tubes were changed.

Preventive Actions:

Since this was probably an involuntary mistake made by the client, the engineering department of the HB Hospitalar was communicated immediately to take preventive actions to avoid similar occurrences in the future. It was determined:

1. To use tracheal-type tubing, plain inside with reinforced rings outside to prevent kinking of the tube and interruption of the flow, regardless of the degree of curvature of the tubing (a series item in the manufacture);

2. Specific orientation regarding the procedure of the circular filter operation (assembly and simulations), including a revision of the Manual of the Equipment with emphasis on this item; and

3. The immediate substitution of the tubing of the client's equipment (who was satisfied with the actions taken and sent us a communication reporting the improvements). Conclusion:

We should mention that HB Hospitalar Ind. e Com. Ltda has been in the market for 55 years, manufacturing and commercializing anesthesia equipment. It is a company with national and international certifications, according to the pertinent legislation, and has sold 220 units of the Conquest 3000 model without any non-conformities secondary to project flaws, performance, or safety. All those statements can be confirmed on consumer protection agencies in the ANVISA web site (www.anvisa.gov.br) or with its clients in Brazil and abroad.

The report mentioned above should have analyzed all facts, especially the conclusions of the manufacturer and the client, in view of the severity of the case, making public, besides the study of the case, the corrective actions taken that demonstrate concern with the most important parties, i.e., the patient and the client.

Thank you very much,

Harry Baukelmann
Director
HB Hospitalar Ind. e Com Ltda.

\section{Réplica}

\section{Sra. Editora,}

Em resposta a réplica pela HB Hospitalar Indústria e Comércio Ltda., através de sua Gerência Administrativa, ao artigo "Barotrauma Pulmonar no Intra-Operatório de Procedimento Cirúrgico Oftalmológico. Relato de Caso", publicado na Rev Bras Anestesiol, 2008;58(1):63-68, vimos esclarecer: $\mathrm{O}$ aparelho em questão, em período de garantia, fez parte de um lote de quatro unidades, adquirido em caráter emergencial pela Secretaria Municipal de Saúde do Rio de Janeiro. De acordo com a chefia do Serviço à época, os mesmos teriam sido montados, como de praxe, pelo fabricante. Todos obedecendo à mesma configuração, não tendo partido da mesma qualquer solicitação para alterações nas condições originais dos referidos equipamentos. Em nosso entender, ainda que o usuário houvesse solicitado alterações que viessem a oferecer riscos operacionais, estas deveriam ser 